\title{
Opposite effects of bombesin on insulin and gastrin response to food in humans
}

\author{
C SCARPIGNATO AND B MICALI \\ From the Laboratory of Clinical Pharmacology, Institute of Pharmacology, University of Parma and \\ Department of Surgical Sciences, University of Messina, Messina, Italy
}

SUMMARY The effect of bombesin on insulin and gastrin response to a standard labelled meal was studied in eight healthy male volunteers. The gastric emptying of solids was simultaneously evaluated. During intravenous infusion of the peptide $(5 \mathrm{ng} / \mathrm{kg} / \mathrm{min})$ the insulin release after eating was greatly reduced whereas food stimulated gastrin release was significantly enhanced. Both effects of bombesin are likely to be connected with the marked inhibition of gastric emptying induced by the peptide.

Bombesin is a frog skin tetradecapeptide which has been found to have similar immunologically characterised counterparts in mammalian gut. ${ }^{1-3}$ An heptacosapeptide has been isolated from porcine non-antral gastric tissue: the so called gastrin releasing peptide (GRP) ${ }^{4}$ The homology of its C-terminal decapeptide with C-terminal decapeptide of bombesin is impressive. As a consequence, both these peptides have the same spectrum of biological actions, although some qualitative differences have been reported.

Many radioimmunological and immunocytochemical observations indicate that bombesin like peptides are confined to neurones and fibres of the intramural plexus of the gut. ${ }^{67}$ As a consequence, they have been put forward as putative neurotransmitters in mammalian gut.

Bombesin was shown to be a potent and polivalent releaser of several gastrointestinal hormones both in animals and humans. ${ }^{8}$ Its gastrin releasing effect, first demonstrated in dogs, firmed in other animal species including man. ${ }^{8}{ }^{10} \mathrm{On}$ the contrary, results concerning its effect on insulin secretion have been contradictory. A stimulation of insulin release was observed in dogs, ${ }^{11}$ cats, ${ }^{12}$ and $\operatorname{man}^{13} 14$ whereas an inhibition was reported in rats. ${ }^{15}$ In vitro studies have provided conflicting results, as well. In fact, whereas bombesin stimulates insulin secretion in isolated and perfused pancreas from dogs ${ }^{16}$ and rats $^{17}$ it inhibits the hormone release from isolated rat pancreatic islets. ${ }^{18}$

Address for correspondence: Prof Carmelo Scarpignato. Laboratory of Clinical Pharmacology. Institute of Pharmacology, Maggiore University Hospital, 43100 Parma. Italy.

Received for publication 28 August 1985.
The recent discovery of bombesin like immunoreactivity in the human pancreas ${ }^{13}$ suggests that this peptide may also affect human pancreatic secretion. Therefore we decided to study in man its effect on insulin response to food. Because bombesin was shown to affect gastric emptying, ${ }^{19}$ the effect of the peptide on emptying rate was simultaneously evaluated.

Preliminary results of the present investigation have been presented at the Italian Society of Gastroenterology (June 1981) and appeared in abstract form. ${ }^{20}$

\section{Methods}

SUBJECTS

Eight male volunteers (average age 24 years) participated in the study after having given written informed consent. They were medical students without any gastrointestinal, endocrine, or metabolic disease. When compared with average weights based on heights and age (Tables Geigy), all the subjects were within $10 \%$ of their predicted (ideal) value.

\section{EXPERIMENTAL DESIGN}

After an overnight fast, all the subjects reached the laboratory at $08.30 \mathrm{am}$. They remained in the supine position during the entire period of the study, except when eating when they were in a semirecumbent position. Two indwelling intravenous cannulae were inserted in the forearms: one for the infusions, the other for blood sampling. All the volunteers underwent the test twice, having an intravenous infusion of bombesin on one occasion and a control saline 
infusion on the other, in a single blind randomised order. Infusion of bombesin (gift of Dr Chiara De Paolis, Farmitalia-Carlo Erba Research Labs, Milan, Italy) in saline $(5 \mathrm{ng} / \mathrm{kg} / \mathrm{min}$ corresponding to $185 \mathrm{pmol} / \mathrm{kg} / \mathrm{h}$ ) began 15 minutes before the meal and continued for 60 minutes. Blood samples for insulin, gastrin, and glucose assays were taken before and after the meal (see Figures).

During the infusion of the peptide, three subjects suffered slight discomfort in the form of nausea (one case) or abdominal discomfort (two cases), but this disappeared spontaneously after stopping the infusion.

\section{MEASUREMENT OF GASTRIC EMPTYING}

Gastric emptying was measured by a method previously described and validated. ${ }^{21}$ Briefly, the subjects ate a standard meal (containing $70 \mathrm{~g}$ carbohydrates, $24 \mathrm{~g}$ proteins, and $24 \mathrm{~g}$ fat) of hamburgers and potatoes purée. Its volume was $400 \mathrm{ml}$ and its caloric value 600 calories. The purée was prepared instantly from commercially lyophilized potatoes, water, milk and a small quantity of butter. This was lightly homogenised using an electric blender after addition of $250 \mu \mathrm{Ci}$ of ${ }^{99 \mathrm{~m}} \mathrm{Tc}$ sulphur colloid.

The subjects were asked to eat the meal in about eight minutes followed by a drink of $200 \mathrm{ml}$ partially skimmed milk. Soon after finishing the meal, they returned to the supine position and radioactivity was continuously recorded for 90 minutes by means of a scintillation detector (Nuclear Accessories, Castiglione O, VA) positioned over the stomach. All data recorded during the time of the study were corrected for radioisotope decay. From these corrected data the percentage of the volume remaining in the stomach (as percentage of radioactivity) was obtained at various time intervals (every 10 minutes).

The radiation absorbed dose, using this method, is very low. 22 Dosimetric calculations done in our laboratory, ${ }^{23}$ however, suggested that male subjects are more suitable than female for this type of study. Indeed, the absorbed dose to the ovaries was higher than that absorbed to testes.

\section{LABORATORY ANALYSIS}

Blood was collected in prechilled tubes containing $1.2 \mathrm{mg}$ of EDTA per $\mathrm{ml}$ of blood. Specimens were centrifuged within one hour and plasma stored at $-20^{\circ} \mathrm{C}$ until the time of assay.

Protein free filtrates for plasma glucose were made immediately after the blood samples had been obtained. Plasma glucose was then determined on the supernatant by using a semimicro glucoseoxidase method. ${ }^{24}$

Plasma immunoreactive insulin (IRI) was assayed by the double antibody method of Hales and Randle, ${ }^{25}$ using a Liso-phase insulin system (Lepetit Diagnostic Products, Milan). In this assay the separation of insulin bound to antibody from unbound insulin was carried out by affinity chromatography (Sepharose gel to which the second antibody has been covalently linked ${ }^{26}$ ). Human insulin was used as a standard and diluted in insulin-free human plasma. In our hands, the method has an intraassay coefficient of variation of $3 \%$; the minimal sensitivity of this method is $2 \mu \mathrm{U} / \mathrm{ml}$.

Plasma immunoreactive gastrin (IRG) was measured by radioimmunoassay ${ }^{27}$ using CIS reagents. The antiserum, produced in rabbits against a G-17 I BSA-conjugate, crossreacted with G-17 I by $100 \%$, with G-17 II by $73 \%$ and with G-34 by $38 \%$ on a weight basis. Synthetic human gastrin (ICI) was used as a standard and diluted in gastrin free human plasma. The method has an intraassay coefficient of variation of $10 \%$ and its sensitivity is sufficient to measure $20 \mathrm{pg} / \mathrm{ml}$ of IRG in a plasma sample.

Bombesin did not interfere in the insulin or gastrin radioimmunoassay at the concentrations used. In both assays all samples from a single subject were assayed in the same run in order to avoid interassay variations.

EVALUATION OF DATA

The fitting of the standard curves of radioimmunoassays was done by a LKB-WALLAC computer on line with the Rack-Gamma using the spline approximation. ${ }^{28}$ Quantitative evaluation of hormone production was made by an integration of areas under the curve of immunoreactivities in plasma, after subtraction of the basal values. From this an immunoreactive insulin production rate in $\mu \mathrm{U} / \mathrm{ml} \cdot \mathrm{min}$ and an immunoreactive gastrin production rate in $\mathrm{pg} / \mathrm{ml} \cdot \mathrm{min}$ were calculated by dividing the respective area by the time $(\mathrm{min})$ of the duration of the test.

There are many approaches to analysing and reporting gastric emptying data. Plotting the emptying curves is the best way to examine and display the details of the emptying process. For comparison between different groups of subjects or different treatments, however, the whole emptying curve rather than specific time points should be taken into account. We used two ways to analyse gastric emptying data. First, we calculated an emptying half-time from the regression lines for the log gastric content against time. ${ }^{21}$ Second, we calculated from each curve an emptying index ${ }^{29}$ according to the formula reported below:

$$
\mathrm{EI}=\left[\frac{100-\mathrm{RRgo}}{\mathrm{Ago}}\right] \times 100
$$


where RRgo is the residual radioactivity 90 minutes after the meal and Ago is the area under the radioactivity time curve. This index was also adopted because its use does not require a choice to be made with regard to the emptying pattern.

All values are presented as a mean \pm SEM. The two way analysis of variance was used for statistical evaluation of data. Student's $t$ test for paired data was used to check differences between the means of summarised responses (emptying half-times, emptying indexes, and integrated hormone reponses). ${ }^{30}$

\section{Results}

HORMONE RESPONSE TO FOOD

Bombesin, administered by intravenous infusion $(5 \mathrm{ng} / \mathrm{kg} / \mathrm{min})$ to healthy volunteers blunted the expected postprandial increase in plasma glucose and concomitantly blocked the insulin response to meal (Fig. 1), an effect which lasts as long as the infusion. After stopping the peptide administration, plasma glucose increased slightly and an insulin response became evident so that plasma hormone levels 60 to 150 minutes after the meal were not significantly different from those observed during saline infusion (Fig. 1).

The background infusion of bombesin increased the gastrin response to food (Fig. 2) as already described in $\operatorname{dogs}^{31}$ and man. ${ }^{32}$

Figure 3 depicts the immunoreactive gastrin secretory rates after the meal with or without bombesin infusion together with the immunoreactive insulin secretory rates. It is evident that bombesin exerts an opposite effect on gastrin and insulin response to meal; that is an increase of the former and a decrease of the latter.

\section{GASTRIC EMPTYING}

During the infusion of the peptide a considerable delay in gastric emptying of solids was observed (Fig. 4) Indeed, bombesin caused a significant increase in emptying half-times and a significant decrease in emptying indexes (both expression of a decrease in emptying rate, see Table).

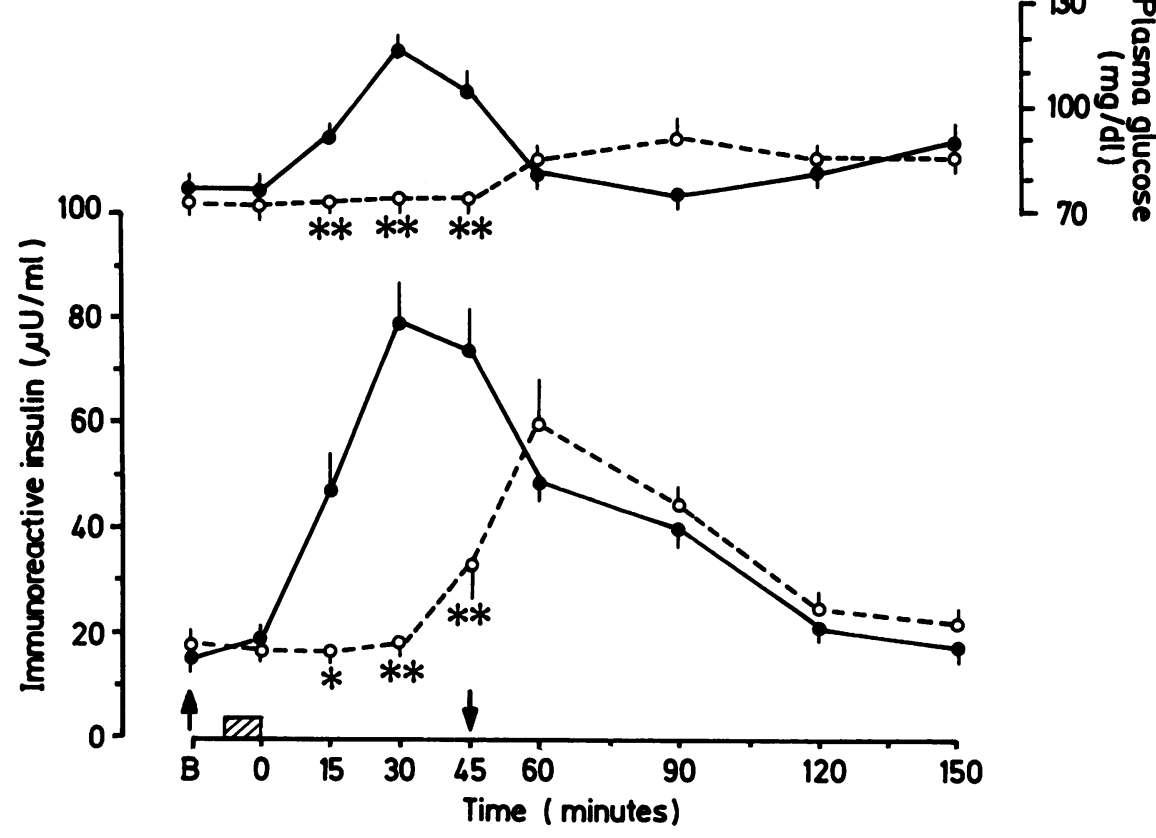

Fig. 1 Plasma insulin and glucose after meal during saline (continuous line) or bombesin (broken line) infusion in eight male volunteers. Each point refers to the mean of the values obtained from eight subjects. Vertical bars are standard errors. Arrows represent the time of beginning and of stopping the infusion, respectively. B (basal) refers to the mean of two consecutive blood samples ( -30 and $-15 \mathrm{~min}$ ) obtained before bombesin or saline infusion. The hatched horizontal bar represents the duration of meal. ${ }^{*} p<0.05{ }^{* *} p<0.02$ 


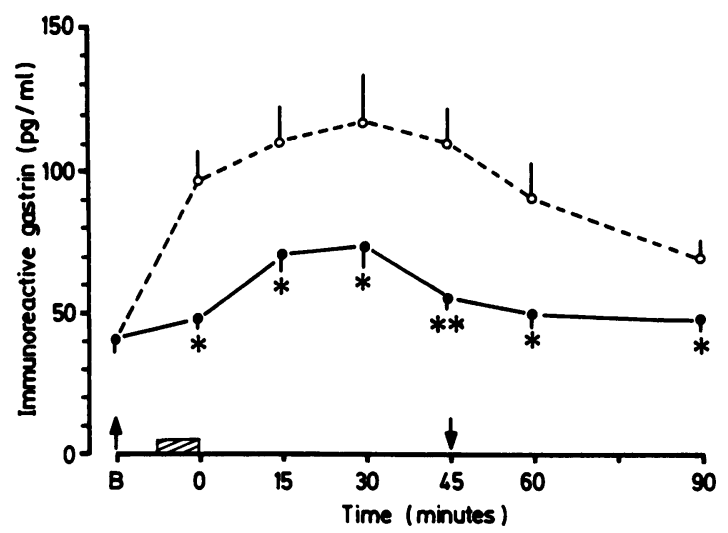

Fig. 2 Plasma gastrin response to food during saline (continuous line) or bombesin (broken line) infusion in eight male volunteers. Each point refers to the mean of the values obtained from eight subjects. Vertical bars are standard errors. Arrows represent the time of beginning and of stopping the infusion, respectively. $B$ (basal) refers to the mean of two consecutive blood samples ( -30 and $-15 \mathrm{~min}$ ) obtained before bombesin or saline infusion. The hatched horizontal bar represents the duration of meal. ${ }^{*} p<0.05$ ${ }^{* *} p<0.02$.
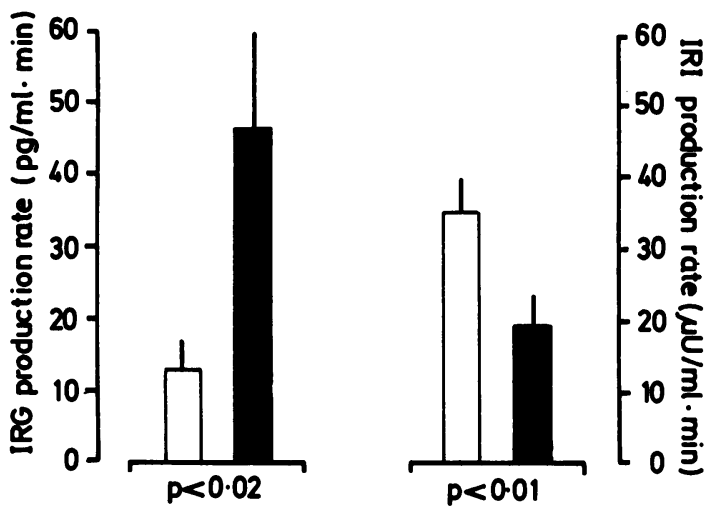

Fig. 3 Integrated responses of immunoreactive gastrin and immunoreactive insulin during saline (white columns) or bombesin (black columns) infusion in eight male volunteers. Each column represents the mean of the values obtained from eight subjects. Vertical bars are standard errors.

Table Emptying half-times (min) and emptying indexes (both presented as mean $\pm S E M$ ) in eight healthy volunteers during saline or bombesin infusion.

\begin{tabular}{lll}
\hline Treatment & Emptying half-time & Emptying index \\
\hline Saline & $81 \cdot 2 \pm 12 \cdot 0$ & $0 \cdot 88 \pm 0 \cdot 12$ \\
Bombesin & $190 \cdot 0 \pm 23 \cdot 1^{*}$ & $0 \cdot 41 \pm 0 \cdot 06^{*}$ \\
\hline
\end{tabular}

${ }^{*} \mathrm{p}<0.02$ in comparison with saline value

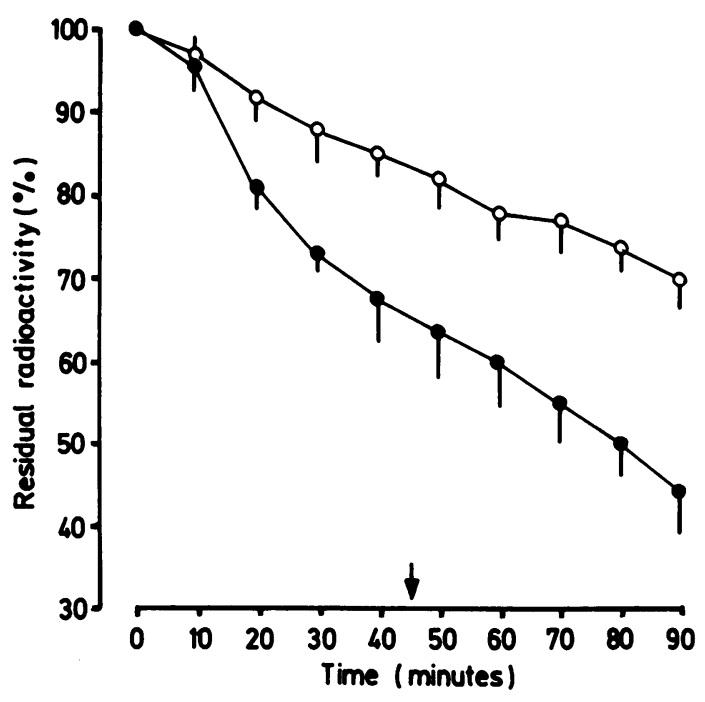

Fig. 4 Time course of residual radioactivity in stomach of eight male volunteers during saline $(O)$ or bombesin $(O)$ infusion. Each point represents the mean of the values obtained from eight subjects. Vertical bars are standard errors. Arrow represents time of stopping of the infusion.

\section{Discussion}

In 1971 Erspamer ${ }^{33}$ first reported that intravenous infusion of alytesin, a frog peptide of the bombesin family, causes a three-fold increase of immunoreactive insulin levels in dogs. Some years later Brown and coworkers ${ }^{34}$ showed that, like other peptides, bombesin can influence glucose homeostasis and affect insulin secretion. Afterwards, insulin release was found to be stimulated by the peptide in cats, ${ }^{12}$ dogs $^{11}$ and man. ${ }^{13}{ }^{14}$ In addition, preliminary experiments of our laboratory ${ }^{35}$ indicated that bombesin also enhances the insulin response to intravenous glucose.

Results obtained in the present investigation show that the insulin response to a standard mixed meal is almost completely suppressed when bombesin is infused intravenously. This unexpected finding, however, is only in apparent contrast with previous data. The lack of postprandial hyperglycaemia and the consequent inhibition of insulin release are likely to be connected with the strong inhibition of gastric emptying, the delay of which slows the entry of the chyme into the duodenum. In accordance with our results, Salera et $a l^{36}$ reported quite recently that during bombesin administration to healthy volunteers the oral glucose load was followed by a flattened glucose curve and a significant inhibition of insulin release. On the other hand, Jorde $e t a l^{37}$ found that in Billroth II resected 
patients an 80 minute ingestion of glucose was followed by serum insulin concentrations significantly lower than that observed after a two minute ingestion of the same quantity of glucose. These data suggest that the rate of glucose delivery into the intestine is of importance in the insulin response to oral stimuli (glucose or mixed meal). In line with these conclusions, Thompson et al ${ }^{38}$ showed that gastric emptying is a determinant of oral glucose tolerance test and actually suggested the possible use of this latter for the assessment of emptying rate.

The flat plasma glucose pattern observed in our volunteers during bombesin infusion raises the possibility of an interference of the peptide with the intestinal glucose absorption, either directly or through an inhibition of intestinal motility. ${ }^{39}$ In a rat model, however, bombesin failed to affect jejunal glucose absorption. ${ }^{40}$ In addition, we $e^{41}$ recently showed that there are no differences in plasma glucose concentrations during bombesin or saline infusion after an intraduodenal glucose load in healthy volunteers. These data suggest that, on the whole, the motor effect of bombesin on the intestine is of less importance in comparison with the enormous capacity of the upper intestine for glucose absorption. ${ }^{42}$

As regards gastrin secretion, our data show that bombesin is not only a potent gastrin releaser 10 but also enhances the gastrin response to meal. Various factors are thought to be involved in the regulation of gastrin release. Among these, the meal residence time in the stomach represents the most often neglected one. Quite recently, Hirschowitz ${ }^{43}$ demonstrated in dogs that the longer hypertonic liquid meals remain in the stomach, a more sustained gastrin response is seen than that with rapidly emptying, hypotonic fluids. In our experimental conditions gastric emptying of solids was strongly inhibited by bombesin and consequently the time food remained in the stomach was considerably increased. This longer time of contact between digesta and antral $G$ cells may account, at least partially, for the increased gastrin response to meal.

To summarise, bombesin administration strongly reduced insulin response to meal and significantly enhanced food induced gastrin release. Both these effects are likely to be connected with the marked inhibition of gastric emptying induced by the peptide.

The exact physiological significance of these observations remains to be established. According to Grossman's criteria, ${ }^{44}$ one of the conditions to be satisfied before an action of a gastrointestinal hormone can be considered 'physiological' is the demonstration that infusion of the hormone to plasma concentrations comparable with those found after a meal induces such an action. In dogs ${ }^{45}$ as well as in $\operatorname{man}^{10}$ no increase in plasma bombesin like immunoreactivity was detected after a meal. Because mammalian bombesin like peptides appear to be confined to nerves of the gastrointestinal tract, ${ }^{6}{ }_{7}$ however, such peptide might have a neural rather than hormonal role. $^{46}$

This work was supported by grants from CNR and MPI (Rome). We are indebted to Roberto Tramacere for verifying the references and to Antonella Pezzetta for her expert technical assistance.

\section{References}

1 Anastasi A, Erspamer V, Bucci M. Isolation and structure of bombesin and alytesin, two analogous active peptides from the skin of the European amphibians bombina and alytes. Experientia 1971; 27: 166-7.

2 Erspamer V, Melchiorri P. Active polypeptides: from amphibian skin to gastrointestinal tract and brain of mammals. Trends Pharmacol Sci 1980; 1: 391-5.

3 Brown M, Vale W. Bombesin: a putative mammalian neurogastrointestinal peptide. Trends Neurosci 1979; 2: 95-7.

4 McDonald TJ, Jornvall H, Nilsson G, et al. Characterization of a gastrin releasing peptide from porcine non antral gastric tissue. Biochem Biophys Res Commun 1979; 90: 227-33.

5 Fletcher DR, Shulkes A, Bladin PHD, Hardy KJ. The effect of atropine on bombesin and gastrin releasing peptide stimulated gastrin, pancreatic polypeptide and neurotensin release in man. Regul Peptides 1983; 7: 31-40.

6 Docray GJ, Vaillant C, Walsh JH. The neuronal origin of bombesin-like immunoreactivity in the rat gastrointestinal tract. Neuroscience 1979; 4: 1561-8.

7 Costa M, Furness JB, Yanaihara C, Moody TW. Distribution and projections of neurons with immunoreactivity for both gastrin-releasing peptide and bombesin in the guinea-pig small intestine. Cell Tissue Res 1984; 235: 285-93.

8 Bertaccini G. Endogenous substances which can affect gastrointestinal motility. In: Bertaccini G. ed. Handbook of experimental pharmacology. Vol 59/II, Heidelberg: Springer-Verlag, 1982:1-10.

9 Bertaccini G, Erspamer V, Melchiorri P, Sopranzi N. Gastrin release by bombesin in the dog. Br J Pharmacol 1974; 52: 219-25.

10 Varner AA, Modlin IM, Walsh JH. High potency of bombesin for stimulation of human gastrin release and gastric acid secretion. Regul Peptides 1981; 1: 289-96.

11 Vaysse N, Pradayrol L, Chayvialle JA, et al. Effects of somatostatin-14 and somatostatin-28 on bombesinstimulated release of gastrin, insulin and glucagon in the dog. Endocrinology 1981; 108: 1843-7.

12 Vagne M, Gelin ML, McDonald TJ, Chayvialle JA, Minaire Y. Effect of bombesin on gastric secretion and motility in the cat. Digestion 1982; 24: 5-13. 
13 Ghatei MA, Jung RT, Stevenson JC, et al. Bombesin: action on gut hormones and calcium in man. J Clin Endocrinol Metab 1982; 54: 980-5.

14 Bruzzone R, Tamburrano G, Lala A, et al. Effect of bombesin on plasma insulin, pancreatic glucagon and gut glucagon in man. J Clin Endocrinol Metab 1983; 56: 643-7.

15 Brown MR, Rivier J, Vale W. Bombesin affects the central nervous system to produce hyperglycemia in rats. Life Sci 1977; 21: 1729-34.

16 Ipp E, Unger RH. Bombesin stimulates the release of insulin and glucagon, but not pancreatic somatostatin, from the isolated perfused dog pancreas. Endocr Res Commun 1979; 6: 37-42.

17 Martindale R, Levin S, Alfin-Slater R. Effects of caerulein and bombesin on insulin and glucagon secretion from the isolated, perfused rat pancreas. Regul Peptides 1982; 3: 313-24.

18 Taminato T, Seino Y, Goto Y, et al. Bombesin inhibits insulin release from isolated pancreatic islets of rats in vitro. Endocrinol Jpn 1978; 25: 305-7.

19 Scarpignato C, Micali B, Vitulo F, Zimbaro G, Bertaccini $G$. Inhibition of gastric emptying by bombesin in man. Digestion 1982; 23: 128-31.

20 Scarpignato C, Micali B, D'angelo A, Bertaccini G. Inhibition of food stimulated insulin release and potentiation of food stimulated gastrin release by bombesin in man. Ital J Gastroenterol 1981; 13: 274.

21 Scarpignato C. Radioisotopic measurement of gastric emptying in man: a tool for assessing drug effect on gastric motility. In: Raynaud $\mathrm{C}$ ed. Nuclear medicine and biology. Vol 1, Oxford: Pergamon Press, 1982: 265-9.

22 Ku RK, Malmud LS, Knight LC, Siegel JA, Stern H, Zelac R. Radiation dose calculations for orally administered radio-pharmaceuticals in upper gastrointestinal disease. In: Raynaud C ed. Nuclear medicine and biology. Vol III, Oxford: Pergamon Press, 1982: 2961-3.

23 Vitulo F, Parisi E, Zimbaro G, Bonanno N, Scarpignato C. Valutazione della dose assorbita durante misura del tempo di svuotamento gastrico con metodo radioisotopico. Diagnostica Immagini 1983; 3: 172-7.

24 Trinder P. Determination of glucose in blood using glucose oxidase with an alternative oxygen acceptor. Ann Clin Biochem 1969; 6: 24-7.

25 Hales CN, Randle PJ. Immunoassay of insulin with insulin-antibody precipitate. Biochem $J$ 1963; 88: $137-46$.

26 Cornale P, Bonazzi M, Multinu C, Romelli P, Vancheri L, Pennisi F. Column affinity chromatography for bound/free separation in ligand assays. I. Radioimmunoassay of choriomammotropin (human placental lactogen). Clin Chem 1981; 27: 896-900.

27 Schrumpf E, Sand T. Radioimmunoassay of gastrin with activated charcoal. Scand J Gastroenterol 1972; 7: 683-7.

28 Marschner I, Herndl R, Scriba PC. Comparison of four different algorithms for the calculation of radioimmunoassay standard curves. J Clin Chem Clin Biochem 1980; 18: 105-9.
29 Grimes DS, Goddard J. Gastric emptying of whole meal and white bread. Gut 1977; 18: 725-9.

30 Elashoff JD. Down with multiple t tests! Gastroenterology 1981; 80: 615-20.

31 Modlin IM, Lamers C, Walsh JH. Mechanisms of gastrin release by bombesin and food. J Surg Res 1980; 28: $539-46$.

32 Lezoche E, Matarazzo PF, Carlei I, et al. Inhibition of food stimulated pancreatic polypeptide (PP) and potentiation of food stimulated gastrin by bombesin (BBS) in man. Ital J Gastroenterol 1979; 11: 137.

33 Erspamer V. Biogenic amines and active polypeptides of the amphibian skin. Ann Rev Pharmacol 1971; 11: 327-50.

34 Brown MR, Fisher DA. Glucoregulation and the sympathetic nervous system: CNS control by brain peptides. In: Bloom FE ed, Peptides: integrators of cells and tissue function. New York: Raven Press, 1980: 81-97.

35 Scarpignato C, Micali B, Gioffrè M, Bertaccini G. Enhancement of glucose-induced insulin secretion by bombesin in man. Ital J Gastroenterol 1983; 15: 208.

36 Salera M, Giacomoni P, Hanssen LE, et al. Effect of bombesin on fasting and glucose-stimulated gastric inhibitory polypeptide (GIP) release in man. Ital J Gastroenterol 1983; 15: 241-5.

37 Jorde R, Schulz TB, Burhol PG, Schulz LB. The response of plasma gastric-inhibitory polypeptide (GIP) to slow and fast glucose ingestion in Billroth II resected patients and normal controls. Regul Peptides 1981; 2: 391-9.

38 Thompson DG, Wingate DL, Thomas M, Harrison D. Gastric emptying as a determinant of the oral glucose tolerance test. Gastroenterology 1982; 82: 51-5.

39 Corazziari E, Torsoli A, Delle Fave GF, Melchiorri P, Fortunee IH. Effects of bombesin on the mechanical activity of the human duodenum and jejunum. Rend $R$ Gastroenterol 1974; 6: 55-9.

40 Andrew NJ, Rinno-Barmada S, Burdett K, Elder JB. Effects of porcine gastric fundic factor, somatostatin, substance $\mathrm{P}$, glucagon, neurotensin, bombesin, VIP, motilin, and pentagastrin on jejunal glucose absorption in the rat. Gut 1983; 24: 326-2.

41 Scarpignato C, Micali B, Bertaccini G. The effect of bombesin on insulin secretion and glucose tolerance in man. In: Abstracts of the XXII Congress of the Ialian Pharmacological Society, Bologna, 1984: 334.

42 Thomson ABR, Weinstein WM. Transport kinetics of D-glucose in human small intestinal mucosa: rate constants in histologically normal and abnormal mucosal biopsies. Dig Dis Sci 1979; 24: 442-8.

43 Hirschowitz BI. Gastrin release in fistula dogs with solid compared to nutrient and non-nutrient liquid meals. Dig Dis Sci 1983; 28: 705-11.

44 Grossman MI. What is physiological? Gastroenterology 1973; 65: 994.

45 Lambert JR, Hansky J, Soveny C, Hunt P. Comparative effects of bombesin and porcine gastrin-releasing peptide in the dog. Dig Dis Sci 1984; 29: 1036-40.

46 Grossman MI. Neural and hormonal regulation of gastrointestinal function: an overview. Ann Rev Physiol 1979; 41: 27-33. 